\title{
Yield and nitrogen use efficiency of rice-wheat cropping system in gypsum amended saline-sodic soil
}

\author{
Behzad Murtaza $^{1 *}$, Ghulam Murtaza ${ }^{2}$, Muhammad Imran $^{1}$, Muhammad Amjad $^{1}$, Asif \\ Naeem, Gulam Mustafa Shah ${ }^{1}$, Abdul Wakeel ${ }^{2 *}$ \\ ${ }^{I}$ Department of Environmental Sciences, COMSATS Institute of Information Technology, Vehari, Pakistan. \\ ${ }^{2}$ Institute of Soil and Environmental Sciences, University of Agriculture, Faisalabad-38040, Pakistan. *Co- \\ rresponding author: behzadmurtaza@ciitvehari.edu.pk
}

\begin{abstract}
It is critical to determine nitrogen use efficiency (NUE) to find to which extent higher rates of nitrogen can improve crop yield with effective management practices. Two-year field experiments were conducted to investigate yield and NUE of rice-wheat cropping system on saline-sodic soil. Treatments included were two nitrogen $(\mathrm{N})$ application rates, i.e. $15 \%\left(\mathrm{~N}_{115}\right)$ and $30 \%\left(\mathrm{~N}_{130}\right)$ higher than the recommended rates for normal soil, along with gypsum at the rates of $50 \%\left(\mathrm{SGR}_{50}\right)$ and $100 \%\left(\mathrm{SGR}_{100}\right)$ of soil gypsum requirement. Results revealed relatively highest $\mathrm{NO}_{3}^{-}$leaching for rice (161 and $\left.145 \mathrm{mg} \mathrm{L}^{-1}\right)$ and for wheat $\left(97\right.$ and $\left.93 \mathrm{mg} \mathrm{L}^{-1}\right)$ during 2011-12 and 2012-13, respectively in $\mathrm{N}_{130}+\mathrm{SGR}_{100}$. In this treatment, crop yield and NUE were the highest as compared to the other combinations. This resulted in reduction of yield gap by two-fold ( $53 \%$ to $26 \%$ ) between saline-sodic and normal soils for rice-wheat. Interestingly, $\mathrm{N}_{130}+\mathrm{SGR}_{100}$ proved most effective during the first year, however, $\mathrm{N}_{100}+\mathrm{SGR}_{100}$ became more profitable in the subsequent year. Pearson correlation coefficients predicted significant positive correlation $(p<0.01)$ of yield and NUE with soil organic matter, cation exchange capacity and infiltration rate while inverse relationship was observed with electrical conductivity, $\mathrm{pH}, \mathrm{CaCO}_{3}$, and bulk density. Based on data, it is concluded that the recommended $\mathrm{N}$ application together with $\mathrm{SGR}_{100}$ would be environmental-friendly and economically viable option for rice-wheat cropping system in saline-sodic soils.
\end{abstract}

Keywords: Amelioration, nitrate leaching, saline-sodic soil, nitrogen use efficiency, gypsum

\section{Introduction}

The commencement of $21^{\text {st }}$ century is manifested by scarcity of global water resources, environmental pollution, and increased soil and water salinity (Shrivastava and Kumar, 2015). Globally, more than $8 \times 10^{8}$ ha of land is salt-affected either by salinity $\left(3.97 \times 10^{8}\right.$ ha) or sodicity $(4.34 \times$ $10^{8}$ ha) (Rozema and Flowers, 2008). In Pakistan, $29 \%$ of total geographical area $\left(7.961 \times 10^{7} \mathrm{ha}\right)$ is 
arable land, and a significant part $\left(6.67 \times 10^{6}\right.$ ha, i.e. $8.4 \%$ ) of this total area is salt-affected which is rapidly expanding (Khan, 1998). It is estimated that $1.6 \times 10^{6}$ ha of arable land is going out of cultivation every year due to low precipitation, high surface evaporation and irrigation with brackish water (Ghassemi et al., 1995).

Salt-affected soils are characterized by high levels of water-soluble salts, high $\mathrm{pH}$ and high sodium (Na) contents which inhibit plant growth due to salt-induced water stress, specific ion toxicity, ion imbalance or nutritional disorders, oxidative stress, and hormonal imbalances (Munns et al., 2006). In saline-sodic soils, availability and absorption of plant nutrients is severely limited to sustain high crop production due to ion interactions, especially low nitrogen $(\mathrm{N})$ because of its leaching as $\mathrm{NO}_{3}$ at high soil $\mathrm{pH}$, volatilization and de-nitrification losses (Marschner, 2011). Overall, all these factors individually or in combination with each other limit N-use-efficiency (NUE) and the extent of this limitation depends on the salinity/sodicity levels, crop types and species and soil physicochemical properties (Grattan and Grieve, 1999).

There are a number of approaches to improve saltaffected soils, i.e. leaching to flush salts from root zone, application of chemical amendments and phytoremediation (Feizi et al., 2010). The reclamation of saline-sodic soils using gypsum $\left(\mathrm{CaSO}_{4}\right.$. $2 \mathrm{H}_{2} \mathrm{O}$ ), $\mathrm{CaCl}_{2}$, with or without organic manures is cost-effective and easy to implement (Makoi and Verplancke, 2010). Gypsum application improves the physical, chemical and biological properties of saline-sodic soils ultimately enhancing crop production on sustainable basis (Walia and Dick, 2016). Calcium (Ca) from gypsum in salinesodic soil decreases volatilization loss of ammonium $\left(\mathrm{NH}_{4}^{+}\right)$from the applications of $\mathrm{NH}_{4} \mathrm{NO}_{3}$, $\left(\mathrm{NH}_{4}\right)_{2} \mathrm{CO}_{3},\left(\mathrm{NH}_{4}\right)_{2} \mathrm{SO}_{4}$ or ammonium phosphates fertilizers (Arshad, 1999). Moreover, Ca decreases soil $\mathrm{pH}$ by reacting with $\left(\mathrm{NH}_{4}\right)_{2} \mathrm{SO}_{4}$ produced during the urea hydrolysis to form $\mathrm{CaCO}_{3}$ and $\left(\mathrm{NH}_{4}\right)_{2} \mathrm{SO}_{4}$. Since $\left(\mathrm{NH}_{4}\right)_{2} \mathrm{SO}_{4}$ is stable and slightly acidic product, therefore, it reduces $\mathrm{NH}_{3}$ loss to the atmosphere (Arshad, 1999).

Increased $\mathrm{N}$ application compensates the yield reduction due to increasing levels of exchangeable $\mathrm{Na}$ percentage when soil physical properties are not a limiting factor in plant growth (Havlin et al., 2005). Increased uptake of $\mathrm{Ca}^{2+}$ and $\mathrm{Mg}^{2+}$, and decreased uptake of $\mathrm{Na}^{+}$by plants resulting from the application of additional $\mathrm{N}$ were responsible for the greater response to $\mathrm{N}$ at high exchangeable $\mathrm{Na}^{+}$ levels. Thus, it appears that the beneficial effects of additional $\mathrm{N}$ application on crop growth in saline-sodic soils can be attributed to more than one mechanisms. Abdelgadir et al. (2010) reported that $\mathrm{N}$ applied to saline-sodic soil partially alleviates the adverse effects of salinity on photosynthesis, respiration, $\mathrm{N}$ fixation and carbohydrate metabolism through enhanced leaf surface area help in enhancing the salt tolerance of plants mainly through growth dilution effect (it distributes the salt concentration in increased surface area thereby reducing salt concentration over a large area).

A number of studies have demonstrated that soil salinity/sodicity reduced $\mathrm{N}$ absorption by plants especially by decreasing NUE. It is hypothesized that increased $\mathrm{N}$ fertilizer application may improve net $\mathrm{N}$ uptake and ultimately the crop yield. Hardly any information exists that adding $\mathrm{N}$ fertilizer at levels higher than recommended rates in saline-sodic soil can improve crop production, environmental health and economic benefit. Therefore, this work aims to determine the effect of gypsum application on NUE in saline-sodic soil in rice-wheat cropping system. 


\section{Materials and Methods}

\subsection{Experimental set-up and treatments}

Two-year field experiments were conducted at village 132/GB, Dijkot (73. 0653 E, 31.1903 N), District Faisalabad, Pakistan on saline-sodic soil belonging to Typic Calciargids. Treatments were arranged in randomized complete block design (RCBD) with three replicates having a plot size of $7.06 \mathrm{~m} \times 20.45 \mathrm{~m}$. To minimize the boundary effects, treatments were separated with ridges of $0.60 \mathrm{~m}$ width and $0.30 \mathrm{~m}$ height, and $0.5 \mathrm{~m}$ around each plot was left uncropped. The recommended application rates of $\mathrm{N}$ in the region for wheat and rice are $120\left(\mathrm{~N}_{100}\right)$ and $125 \mathrm{~kg} \mathrm{ha}^{-1}\left(\mathrm{~N}_{100}\right)$, respectively. The five treatments of current study include: 1) no fertilizer and no gypsum (control), 2) recommended $\mathrm{N}+$ gypsum at $50 \%$ soil gypsum requirement $\left(\mathrm{N}_{100}+\mathrm{SGR}_{50}\right)$, 3) $30 \%$ higher $\mathrm{N}$ than recommended $\mathrm{N}$ fertilizer + gypsum at $50 \%$ soil SGR $\left(\mathrm{N}_{130}\right.$ $\left.+\mathrm{SGR}_{50}\right)$, and 4) recommended $\mathrm{N}+$ gypsum at 100 $\% \operatorname{SGR}\left(\mathrm{N}_{100}+\mathrm{SGR}_{100}\right)$, and 5) $30 \%$ higher $\mathrm{N}$ than recommended $\mathrm{N}$ fertilizer + gypsum at $100 \% \mathrm{SGR}$ $\left(\mathrm{N}_{130}+\mathrm{SGR}_{100}\right)$.

\subsection{Physico-chemical analysis of soil}

Composite soil samples from 0-15 cm and $15-30 \mathrm{~cm}$ soil depths were drawn from each plot before and after harvest of the subsequent crops. Before analysis, soil samples were air-dried and ground to pass through a $2 \mathrm{~mm}$ sieve for homogenization. Thereafter, samples were analyzed for $\mathrm{pH}_{\mathrm{s}}, \mathrm{EC}_{\mathrm{e}}$, soluble cations $\left(\mathrm{Na}^{+}, \mathrm{K}^{+}\right.$, $\left.\mathrm{Ca}^{2+}, \mathrm{Mg}^{2+}\right)$ and anions $\left(\mathrm{CO}_{3}^{2-}, \mathrm{HCO}_{3}^{-}, \mathrm{Cl}^{-}, \mathrm{SO}_{4}^{-}, \mathrm{NO}_{3}^{-}\right.$ ) following the methods described by Estefan et al. (2013). The $\mathrm{EC}_{\mathrm{e}}$ and $\mathrm{pH}_{\mathrm{s}}$ were determined in saturated paste extracts and saturated soil paste, respectively. Particle-size analysis was carried out by hydrometer method (Rowell, 2014). The gypsum requirement of the saline-sodic soil was determined following the protocol described by Ghafoor et al. (2004), and was applied according to the treatment plan. The amount of gypsum of saline-sodic soil was $5.18 \mathrm{Mg} \mathrm{ha}^{-1}$ and was well mixed with cultivator and wooden roller driven by tractor in the top layer of soil before planting the first rice crop (July 2011).

\subsection{Rice and wheat crop husbandry}

Each year, only one crop of rice and wheat was grown. During the first year, rice (Oryza sativa L., super basmati) seedlings (2-3 seedlings per hill) were transplanted on July 07, 2011 and harvested on November 04, 2011. Row to row and hill to hill distance was maintained at $20 \mathrm{~cm}$. The seedlings were transplanted without puddling the soil. The experimental plots were irrigated with canal water using a cut-throat flume to estimate the amount of water applied. Fertilizers N, phosphorus $(\mathrm{P})$ and potassium (K) were applied at 125,75 and $60 \mathrm{~kg} \mathrm{ha}^{-1}$ as urea, triple super phosphate (TSP) and sulfate of potash (SOP), respectively. Full dose of $\mathrm{P}$ and $\mathrm{K}$, and $1 / 3^{\text {rd }}$ of $\mathrm{N}$ dose were applied at the time of transplantation while the remaining $\mathrm{N}$ was applied in two equal splits at 34 and 46 days after transplantation (DAT) of rice. At physiological maturity, straw and paddy yield were recorded. Soil samples were taken from each experimental plot and were analyzed for physicochemical soil properties after harvest of the rice crops.

Soon after harvest of the first rice crop, wheat (Triticum aestivum L. cv. Faisalabad 2008) was sown using $100 \mathrm{~kg} \mathrm{ha}^{-1}$ seed rate on November 12, 2011 and harvested on April 26, 2012. Sowing was done using a drill machine while maintaining a row to row distance of $20 \mathrm{~cm}$ and a depth of seed in soil at $5 \mathrm{~cm}$. The fertilizers N, P and K were applied at 120-100-60 kg $\mathrm{ha}^{-1}$ as urea, TSP and SOP, respectively. All the P and $\mathrm{K}$ were applied at the time of sowing while half of 
$\mathrm{N}$ was applied at the time of sowing. The remaining $\mathrm{N}$ was applied in two equal splits at tillering i.e. 28 days after germination (DAG) and booting stages (54 DAG). The wheat crop was irrigated five times with known volume of canal water; the first irrigation was applied at day-30 after sowing and subsequent four irrigations were given at an interval of 20 days. The weedicide (Isoproturon $50 \mathrm{WP}$ ) was applied using a Knapsack sprayer 55 days after sowing (i.e. after the second irrigation). After harvesting at maturity, grain and straw yield was recorded. The NUE was calculated using the formula: $\mathrm{kg}$ DM production per $\mathrm{kg} \mathrm{N}$ uptake while agronomic use efficiency was calculated with $\left(\mathrm{Y}_{\mathrm{N}}-\mathrm{Y}_{0}\right) / \mathrm{F}_{\mathrm{N}}$.

Where $\mathrm{Y}_{\mathrm{N}}$ and $\mathrm{Y}_{0}$ are yield with and without $\mathrm{N}$ application, respectively and $\mathrm{F}_{\mathrm{N}}$ is amount of $\mathrm{N}$ fertilizer applied.

Soil samples were collected from each treatment plot after the harvest of both the wheat crops. Samples were analyzed for $\mathrm{pH}_{\mathrm{s}}, \mathrm{EC}_{\mathrm{e}}, \mathrm{SAR}$ and soluble cations and anions by following the methods described by Estefan et al. (2013).

\subsection{Leachate collection}

Ceramic cups were installed at a $60 \mathrm{~cm}$ depth for leachate collection before the transplantation of first rice crop. These cups were installed randomly in the plots ( $2 \mathrm{~m}$ away from the borders). All holes were initially augured at a $65 \mathrm{~cm}$ depth, a slurry of fine sand was then poured into the auger hole and ceramic cups were installed vertically. A plug of bentonite was inserted into the hole during back-filling to prevent water movement along the shaft. Solutions were withdrawn from the cups using a syringe connected to a long tube, and transferred to a storage bottle. Leachate was collected until it had been calculated that drainage from the field had stopped which corresponded to the collection of five leachates during rice cropping and three leachates during wheat cropping. All the leachate samplers were treated with $1 \mathrm{MHCl}$. Leachates were collected by applying 0.06-0.07 MPa suction with the help of suction pump and analyzed within $24 \mathrm{~h}$ of leachate collection, or otherwise stored at temperature $4{ }^{\circ} \mathrm{C}$ until analysis. The experiments were continued under the same management practices for further one year. For rice, during the second year, seedlings were transplanted on July 15, 2012 and harvested on November 17, 2012. While during the second year, wheat crop was sown on November 28, 2012 and harvested on April 28, 2013. Average range of temperature, relative humidity, evapotranspiration and total rainfall received during growing seasons are given in our previous study (Murtaza et al., 2017).

\subsection{Statistical analysis}

Before performing analysis of variance (ANOVA), the data were tested for normality of distribution and homogeneity of variance. Significant differences in physicochemical parameters of rice and wheat were examined using ANOVA. All the data were statistically analyzed using computer software 'Statisix 8.1'. The significant differences between the treatment means were compared using least significant difference (LSD) test at 5\% probability level (Steel et al., 1997). For physicochemical parameters, the value of the Pearson correlation coefficient (r) was calculated at $p \leq 0.05$.

\section{Results}

\subsection{Chemical properties of salt-affected soil during crop growth}

Before the cultivation of wheat 2011-12, $\mathrm{pH}_{\mathrm{s}}, \mathrm{EC}_{\mathrm{e}}$ and SAR of experimental plots ranged from 8.53 to $8.71,7.55$ to $10.53 \mathrm{dS} \mathrm{m}^{-1}$ and 32.61 to 44.51 
$\left.(\mathrm{mmol} \mathrm{L})^{-1}\right)^{1 / 2}$ at $0-15 \mathrm{~cm}$ soil depth, respectively. At $15-30 \mathrm{~cm}$ soil depth, the respective values ranged from 8.50 to $8.69,7.40$ to $8.99 \mathrm{dS} \mathrm{m}^{-1}$ and 34.56 to $36.57\left(\mathrm{mmol} \mathrm{L}^{-1}\right)^{1 / 2}$ (Table 1). After wheat harvest 2012-13, the highest decrease in $\mathrm{pH}_{\mathrm{s}}$ was observed at $\mathrm{N}_{100}+\mathrm{SGR}_{100}$ and the lowest in the control treatment. The treatment $\mathrm{N}_{100}+\mathrm{SGR}_{100}$ remained nonsignificant $(\mathrm{p} \leq 0.05)$ with $\mathrm{N}_{130}+\mathrm{SGR}_{100}$ at $0-15$ $\mathrm{cm}$ soil depth. At 15-30 cm soil depth, the highest decrease in $\mathrm{pH}_{\mathrm{s}}$ was observed with $\mathrm{N}_{100}+\mathrm{SGR}_{100}$ (3.9\%) followed by $\mathrm{N}_{130}+\operatorname{SGR}_{100}(3.7 \%), \mathrm{N}_{100}$ $+\operatorname{SGR}_{50}(3.2 \%), \mathrm{N}_{130}+\operatorname{SGR}_{50}(2.8 \%)$ and control treatment $(0.5 \%)$. In saline-sodic soil, the highest decrease in $\mathrm{EC}_{\mathrm{e}}$ was observed for $\mathrm{N}_{100}+$ $\mathrm{SGR}_{100}(66.51 \%)$ and the lowest was for the control treatment after wheat harvest $2012-13$ at $0-15 \mathrm{~cm}$ soil depth. At 15-30 cm soil depth, the maximum observed reduction in $\mathrm{EC}_{\mathrm{e}}$ at $\mathrm{N}_{130}+\mathrm{SGR}_{100}$ differed significantly $(\mathrm{p} \leq 0.05)$ with the control treatment. Post-wheat crop (2012-13) soil analysis showed a significant decrease in SAR with the varying rates of $\mathrm{N}$ and gypsum (Table 1). The reduction in SAR was the highest for treatment $\mathrm{N}_{100}+\mathrm{SGR}_{100}$ and the lowest for the control treatment. Treatment $\mathrm{N}_{100}+$ $\mathrm{SGR}_{100}$ significantly differed from other treatments except $\mathrm{N}_{130}+\mathrm{SGR}_{100}$ at both the soil depths.

Table 1. Effect of $\mathrm{N}$ and gypsum treatments on $\mathrm{pH}, \mathrm{EC}$ and SAR of salt-affected soil under experiments.

\begin{tabular}{|c|c|c|c|c|c|c|}
\hline \multirow[t]{2}{*}{ Treatment } & \multicolumn{2}{|c|}{$\mathrm{pH}_{\mathrm{s}}$} & \multicolumn{2}{|c|}{$\mathrm{EC}_{\mathrm{e}}\left(\mathrm{dS} \mathrm{m}{ }^{-1}\right)$} & \multicolumn{2}{|c|}{ SAR $(m m o l ~ L-1)^{1 / 2}$} \\
\hline & $\begin{array}{l}{ }^{\text {a Pre- }} \\
\text { wheat } \\
\text { (Nov. } \\
2011 \text { ) }\end{array}$ & $\begin{array}{l}\text { bost- } \\
\text { wheat } \\
\text { May } \\
2013 \text { ) }\end{array}$ & $\begin{array}{l}{ }^{\mathrm{a}} \text { Pre-wheat } \\
\text { (Nov. 2011) }\end{array}$ & $\begin{array}{c}\text { bost- } \\
\text { wheat } \\
\text { (May 2013) }\end{array}$ & $\begin{array}{c}\text { aPre-wheat } \\
\text { (Nov. } \\
\text { 2011) }\end{array}$ & $\begin{array}{l}{ }^{\text {b} P o s t-w h e a t ~} \\
\text { (May 2013) }\end{array}$ \\
\hline \multicolumn{7}{|c|}{$0-15 \mathrm{~cm}$ soil depth } \\
\hline Control & 8.56 & $8.52 \mathrm{a}$ & 8.68 & $5.74 \mathrm{a}$ & 44.51 & $29.86 \mathrm{a}$ \\
\hline $\mathrm{N}_{100}+\mathrm{SGR}_{50}$ & 8.71 & $8.44 \mathrm{ab}$ & 7.55 & $4.51 \mathrm{~b}$ & 37.88 & $16.67 \mathrm{~b}$ \\
\hline $\mathrm{N}_{130}+\mathrm{SGR}_{50}$ & 8.65 & $8.37 \mathrm{bc}$ & 8.49 & $3.49 \mathrm{~d}$ & 32.61 & $14.29 \mathrm{c}$ \\
\hline $\mathrm{N}_{100}+\mathrm{SGR}_{100}$ & 8.53 & $8.21 \mathrm{~cd}$ & 10.53 & $3.53 \mathrm{c}$ & 41.33 & $13.48 \mathrm{~d}$ \\
\hline $\mathrm{N}_{130}+\mathrm{SGR}_{100}$ & 8.55 & $8.25 \mathrm{~d}$ & 9.31 & $3.92 \mathrm{~b}$ & 37.35 & $13.17 \mathrm{~d}$ \\
\hline LSD & NS & $0.11^{*}$ & NS & $0.28^{*}$ & NS & $0.73^{*}$ \\
\hline \multicolumn{7}{|c|}{$15-30 \mathrm{~cm}$ soil depth } \\
\hline Control & 8.54 & $8.49 \mathrm{a}$ & 8.99 & $6.75 \mathrm{a}$ & 35.01 & $25.59 \mathrm{a}$ \\
\hline $\mathrm{N}_{100}+\mathrm{SGR}_{50}$ & 8.69 & $8.41 \mathrm{ab}$ & 7.40 & $4.33 \mathrm{c}$ & 35.85 & $17.39 \mathrm{~b}$ \\
\hline $\mathrm{N}_{130}+\mathrm{SGR}_{50}$ & 8.63 & $8.38 \mathrm{~b}$ & 8.28 & $4.20 \mathrm{c}$ & 36.57 & $16.01 \mathrm{c}$ \\
\hline $\mathrm{N}_{100}+\mathrm{SGR}_{100}$ & 8.50 & $8.17 \mathrm{c}$ & 8.55 & $4.68 \mathrm{~b}$ & 35.37 & $13.66 \mathrm{~d}$ \\
\hline $\mathrm{N}_{130}+\mathrm{SGR}_{100}$ & 8.53 & $8.21 \mathrm{c}$ & 8.55 & $4.03 \mathrm{c}$ & 34.56 & $13.38 \mathrm{~d}$ \\
\hline LSD & NS & $0.10^{*}$ & NS & $0.34^{*}$ & NS & $0.70^{*}$ \\
\hline
\end{tabular}

Values in a column sharing same letter(s) are statistically similar at $p \leq 0.05$; NS, Treatments differed non-significantly at $p \leq$ 0.05; * Treatments differed significantly $p \leq 0.05$. ${ }^{\mathrm{a}}$ Chemical properties before the start of experiment; ${ }^{\mathrm{b}}$ Chemical properties after the harvest of experiment. 


\subsection{Crop growth and yield}

\subsubsection{Rice}

During 2011, paddy yield was significantly ( $p \leq$ 0.05 ) affected by different rates of $\mathrm{N}$ fertilizer (Figure 1). The highest paddy yield of $1.21 \mathrm{t} \mathrm{ha}^{-1}$ was obtained for treatment $\mathrm{N}_{130}+\mathrm{SGR}_{100}$ and the lowest of $0.98 \mathrm{t} \mathrm{ha}^{-1}$ in case of the control treatment. Further, the highest straw yield was obtained with $\mathrm{N}_{130}+\mathrm{SGR}_{100}\left(1.58 \mathrm{tha}^{-1}\right)$ and the lowest (1.38 $\mathrm{t} \mathrm{ha}^{-1}$ ) was with the control treatment. Straw yield was significantly affected due to the different rates of $\mathrm{N}$ fertilizer application along with gypsum i.e. $\mathrm{N}_{100}+\mathrm{SGR}_{50}, \mathrm{~N}_{130}+\mathrm{SGR}_{50}, \mathrm{~N}_{100}+\mathrm{SGR}_{100}$ and $\mathrm{N}_{130}$
$+\mathrm{SGR}_{100}$ treatments. It seemed that $\mathrm{SGR}_{100}$ was necessary to achieve reclamation and obtain rationally high paddy and straw yields on saline-sodic soils. Similarly, during 2012, the maximum paddy yield of $1.92 \mathrm{tha}^{-1}$ was obtained in treatment $\mathrm{N}_{130}+$ $\mathrm{SGR}_{100}$ which remained the highest as compared to the other treatments. Straw yield was also affected significantly at all $\mathrm{N}$ and gypsum application levels (Figure 1) and maximum straw yield of $2.46 \mathrm{t}$ ha $^{-1}$ was observed with $\mathrm{N}_{130}+\mathrm{SGR}_{100}$ which significantly differed with the control treatment, whereas it remained non-significant with other treatments i.e. at $\mathrm{N}_{100}+\mathrm{SGR}_{50}, \mathrm{~N}_{130}+\mathrm{SGR}_{50}$ and $\mathrm{N}_{100}+\mathrm{SGR}_{100}$ treatments respectively.

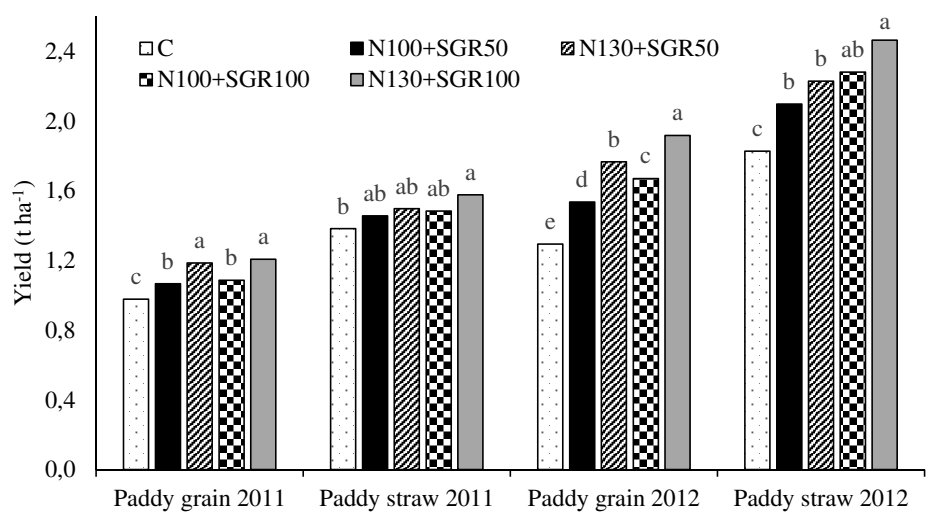

Figure 1. Effect of $\mathrm{N}$ and gypsum application rates on paddy yields in saline-sodic soil, where (C) no fertilizer and no gypsum, $\left(\mathrm{N}_{100}+\mathrm{SGR}_{50}\right)$ recommended $\mathrm{N}+$ gypsum at 50\% $\mathrm{SGR},\left(\mathrm{N}_{130}+\mathrm{SGR}_{50}\right) 30 \%$ higher $\mathrm{N}$ than recommended $\mathrm{N}$ fertilizer + gypsum at $50 \%$ soil $\mathrm{SGR}$, and $\left(\mathrm{N}_{100}+\mathrm{SGR}_{100}\right)$ recommended $\mathrm{N}+$ gypsum at the rate of $100 \% \mathrm{SGR}$, and $\left(\mathrm{N}_{130}+\mathrm{SGR}_{100}\right) 30 \%$ higher $\mathrm{N}$ than recommended $\mathrm{N}$ fertilizer + gypsum at $100 \% \mathrm{SGR}$. Fisher's LSD test $(p \leq 0.05)$ was performed. Treatments which were not significantly different from one another are illustrated with same letter on the columns. SGR=Soil Gypsum Requirement 


\subsubsection{Wheat}

Significant increase in wheat yield was observed in both the years (2011-12 and 2012-13). Among the treatments, the highest wheat grain yield of $\left(3.12 \mathrm{t} \mathrm{ha}^{-1}\right)$ during 2011-12 and 3.53 $\mathrm{t} \mathrm{ha}^{-1}$ during 2012-13 was obtained for $\mathrm{N}_{130}+\mathrm{SGR}_{100}$ but it did not differ from treatment $\mathrm{N}_{100}+\mathrm{SGR}_{100}$ (Figure 2). Overall, it was observed that treatment $\mathrm{N}_{130}+\mathrm{SGR}_{100}$ performed better for grain as well as straw yield.

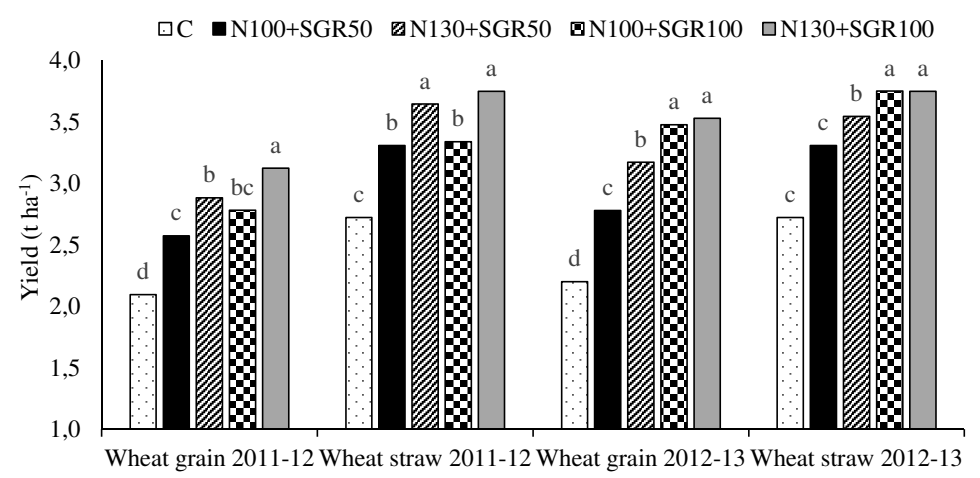

Figure 2. Effect of $\mathrm{N}$ and gypsum application rates on wheat yield during amelioration of saline-sodic soil. (C) no fertilizer and no gypsum, $\left(\mathrm{N}_{100}+\mathrm{SGR}_{50}\right)$ recommended $\mathrm{N}+$ gypsum at $50 \% \mathrm{SGR},\left(\mathrm{N}_{130}+\mathrm{SGR}_{50}\right) 30 \%$ higher $\mathrm{N}$ than recommended $\mathrm{N}$ fertilizer + gypsum at $50 \%$ soil $\mathrm{SGR}$, and $\left(\mathrm{N}_{100}+\mathrm{SGR}_{100}\right)$ recommended $\mathrm{N}+$ gypsum at 100 $\% \mathrm{SGR}$, and $\left(\mathrm{N}_{130}+\mathrm{SGR}_{100}\right) 30 \%$ higher $\mathrm{N}$ than recommended $\mathrm{N}$ fertilizer + gypsum at $100 \% \mathrm{SGR}$. Fisher's LSD tests $(\mathrm{p} \leq 0.05)$ were performed. Any treatment which were not significantly different from one another are illustrated as same letter on the columns. SGR=Soil Gypsum Requirement

\subsection{Agronomic use efficiency and nitrogen use efficiency}

The agronomic use efficiency (AUE) was the highest with $\mathrm{N}_{130}+\mathrm{SGR}_{100}$ treatment while it was the lowest with $\mathrm{N}_{100}+\mathrm{SGR}_{50}$ during both years of rice (2011-12) (Table 2). During wheat crop (2012-13), the highest AUE was associated with $\mathrm{N}_{100}+\mathrm{SGR}_{100}$ which was significantly different from control treatment.

The highest NUE was recorded with control treatment and the lowest with $\mathrm{N}_{130}+\mathrm{SGR}_{100}$ for rice-wheat during both years. In rice 2011, maximum and minimum recorded NUE was 76.95 and $57.19 \mathrm{~kg} \mathrm{~kg}^{-1}$, respectively. While during second year, the highest NUE was observed with control $\left(73.93 \mathrm{~kg} \mathrm{~kg}^{-1}\right)$ treatment and the lowest $\left(50.30 \mathrm{~kg} \mathrm{~kg}^{-1}\right)$ was being with $\mathrm{N}_{130}+\mathrm{SGR}_{100}$. Minimum NUE in rice for both years was observed with $\mathrm{N}_{130}+\mathrm{SGR}_{100}$ and the highest was with control treatment

Similarly, in wheat 2011-12, the highest NUE with control treatment was $86.19 \mathrm{~kg} \mathrm{~kg}^{-1}$ and minimum (63.55 $\mathrm{kg} \mathrm{kg}^{-1}$ ) was observed with $\mathrm{N}_{130}+\mathrm{SGR}_{100}$. While during second year, the highest and lowest recorded NUE was 88.69 and $59.73 \mathrm{~kg} \mathrm{~kg}^{-1}$ with control and $\mathrm{N}_{130}+\mathrm{SGR}_{100}$ treatment. 
Table 2. Effect of applied N rates on NUE and AUE of wheat and rice on salt-affected soil, where (C) no fertilizer and no gypsum, $\left(\mathrm{N}_{100}+\mathrm{SGR}_{50}\right)$ recommended $\mathrm{N}+$ gypsum at 50\% $\mathrm{SGR},\left(\mathrm{N}_{130}+\mathrm{SGR}_{50}\right) 30 \%$ higher $\mathrm{N}$ than recommended $\mathrm{N}$ fertilizer + gypsum at $50 \% \mathrm{SGR}$, and $\left(\mathrm{N}_{100}+\mathrm{SGR}_{100}\right)$ recommended $\mathrm{N}+$ gypsum @ $100 \% \mathrm{SGR}$, and $\left(\mathrm{N}_{130}+\mathrm{SGR}_{100}\right) 30 \%$ higher $\mathrm{N}$ than recommended $\mathrm{N}$ fertilizer + gypsum at $100 \% \mathrm{SGR}$.

\begin{tabular}{|c|c|c|c|c|}
\hline Treatment & Rice 2011 & Wheat 2011-12 & Rice 2012 & Wheat 2012-13 \\
\hline \multicolumn{5}{|c|}{ Nitrogen use efficiency (kg DM production per kg N uptake) } \\
\hline $\mathrm{C}$ & $76.95 \mathrm{a}$ & $86.19 \mathrm{a}$ & $73.93 \mathrm{a}$ & $88.69 \mathrm{a}$ \\
\hline $\mathrm{N}_{100}+\mathrm{SGR}_{50}$ & $69.58 \mathrm{~b}$ & $78.55 \mathrm{~b}$ & $62.77 \mathrm{~b}$ & $76.47 \mathrm{~b}$ \\
\hline $\mathrm{N}_{130}+\mathrm{SGR}_{50}$ & $60.97 \mathrm{c}$ & $68.48 \mathrm{~d}$ & $56.92 \mathrm{c}$ & $67.04 \mathrm{c}$ \\
\hline $\mathrm{N}_{100}+\mathrm{SGR}_{100}$ & $63.29 \mathrm{c}$ & $72.99 \mathrm{c}$ & $54.74 \mathrm{c}$ & $62.77 \mathrm{~d}$ \\
\hline $\mathrm{N}_{130}+\mathrm{SGR}_{100}$ & $57.19 \mathrm{~d}$ & $63.55 \mathrm{e}$ & $50.30 \mathrm{~d}$ & $59.73 \mathrm{e}$ \\
\hline LSD & $3.44^{*}$ & $1.78^{*}$ & $3.09^{*}$ & $2.24^{*}$ \\
\hline \multicolumn{5}{|c|}{ Agronomic use efficiency $\left(\mathrm{Y}_{\mathrm{N}}-\mathrm{Y}_{0}\right) / \mathrm{F}_{\mathrm{N}}$} \\
\hline $\mathrm{N}_{100}+\mathrm{SGR}_{50}$ & $0.70 \mathrm{~b}$ & $3.79 \mathrm{c}$ & $1.92 \mathrm{c}$ & $4.59 \mathrm{c}$ \\
\hline $\mathrm{N}_{130}+\mathrm{SGR}_{50}$ & $1.27 \mathrm{a}$ & $4.83 \mathrm{~b}$ & $2.89 \mathrm{~b}$ & $5.95 \mathrm{c}$ \\
\hline $\mathrm{N}_{100}+\mathrm{SGR}_{100}$ & $0.85 b$ & $5.45 \mathrm{ab}$ & $2.98 \mathrm{~b}$ & $10.13 \mathrm{a}$ \\
\hline $\mathrm{N}_{130}+\mathrm{SGR}_{100}$ & $1.40 \mathrm{a}$ & $6.30 \mathrm{a}$ & $3.83 \mathrm{a}$ & $8.15 b$ \\
\hline LSD & $0.26 *$ & $1.02 *$ & $0.638^{*}$ & $1.838^{*}$ \\
\hline
\end{tabular}

* Treatments differed significantly at $p \leq 0.05$.

The effect of gypsum and $\mathrm{N}$ application rates on $\mathrm{NO}_{3}{ }^{-}$leaching in saline-sodic soil during rice cropping in 2011 and 2012 has been presented in Figure 3. The highest $\mathrm{NO}_{3}^{-}$concentration $\left(42.07 \mathrm{mg} \mathrm{L}^{-1}\right)$ was recorded in the first leachate at $\mathrm{N}_{130}+\mathrm{SGR}_{100}$ which did not differ significantly from the treatment $\mathrm{N}_{100}+\mathrm{SGR}_{50}$. During the second leaching, the lowest amount of $\mathrm{NO}_{3}^{-}\left(1.75 \mathrm{mg} \mathrm{L}^{-1}\right)$ was recorded at control treatment and the highest amount in $\mathrm{N}_{130}+\mathrm{SGR}_{100}$. There was a gradual increase in $\mathrm{NO}_{3}^{-}$concentration in the third, fourth and fifth leachates. The maximum $\mathrm{NO}_{3}^{-}$was recorded in the fifth leachate at $\mathrm{N}_{130}+\mathrm{SGR}_{100}$. During rice cropping (2012), the highest amount of $\mathrm{NO}_{3}^{-}$leaching
(27.35 $\mathrm{mg} \mathrm{L}^{-1}$ ) was recorded at $\mathrm{N}_{130}+\mathrm{SGR}_{100}$ and the lowest amount of $\mathrm{NO}_{3}^{-}$leaching $\left(12.05 \mathrm{mg} \mathrm{L}^{-1}\right)$ was observed at control treatment (Figure 3). In second leachate, a significant decrease in leached $\mathrm{NO}_{3}^{-}$- contents was observed with all applied rates of $\mathrm{N}$ compared to the first leachate. An increase in leached $\mathrm{NO}_{3}{ }^{-}$contents observed during third and fourth leaching seems due to the improvements in infiltration rate (IR) and hydraulic conductivity (HC) of soil with the use of gypsum. In fifth leachate, the lowest $\mathrm{NO}_{3}^{-}$concentration was observed with control treatment and the greatest was with $\mathrm{N}_{130}+\mathrm{SGR}_{100}$ treatment. 

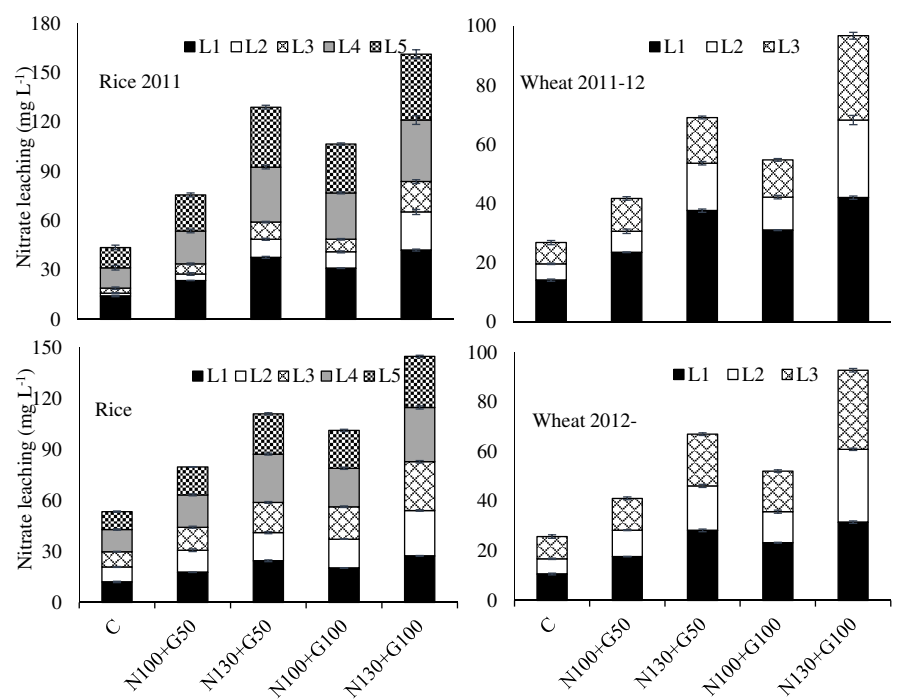

Figure 3. Effect of $\mathrm{N}$ application rates on nitrate leaching during wheat and rice crops on saline-sodic soil. (C) no fertilizer and no gypsum, $\left(\mathrm{N}_{100}+\mathrm{SGR}_{50}\right)$ recommended $\mathrm{N}+$ gypsum at $50 \% \mathrm{SGR},\left(\mathrm{N}_{130}+\mathrm{SGR}_{50}\right) 30 \%$ higher $\mathrm{N}$ than recommended $\mathrm{N}$ fertilizer + gypsum at $50 \%$ soil $\mathrm{SGR}$, and $\left(\mathrm{N}_{100}+\mathrm{SGR}_{100}\right)$ recommended $\mathrm{N}+$ gypsum at $100 \% \mathrm{SGR}$, and $\left(\mathrm{N}_{130}+\mathrm{SGR}_{100}\right) 30 \%$ higher $\mathrm{N}$ than recommended $\mathrm{N}$ fertilizer + gypsum at $100 \% \mathrm{SGR}$. Columns show the values meanwhile bars on columns show standard error. SGR=Soil Gypsum Requirement

The effect of gypsum and $\mathrm{N}$ application rates on $\mathrm{NO}_{3}^{-}$leaching in saline-sodic soil during the wheat cropping (2011-12) is shown in Figure 3. The highest $\mathrm{NO}_{3}{ }^{-}$concentration $\left(42.07 \mathrm{mg} \mathrm{L}^{-1}\right)$ observed in the first leachate was at treatment $\mathrm{N}_{130}+\mathrm{SGR}_{100}$ which did not differ significantly from $\mathrm{N}_{130}+\mathrm{SGR}_{50}$. In the second leachate, a decrease in $\mathrm{NO}_{3}^{-}$concentration were recorded. The lowest $\mathrm{NO}_{3}^{-}$concentration (5.50 $\mathrm{mg} \mathrm{L}^{-1}$ ) was recorded at control treatment and the highest (28.21 $\left.\mathrm{mg} \mathrm{L}^{-1}\right)$ at $\mathrm{N}_{130}+\mathrm{SGR}_{100}$. A decrease in $\mathrm{NO}_{3}^{-}$leaching in the second leachate was attributed to increased uptake of $\mathrm{NO}_{3}^{-}$by plants during the vegetative growth period. There was an increase in $\mathrm{NO}_{3}^{-}$ in the third leachate which seems due to the third $\mathrm{N}$ application coupled with slow growth rate of wheat crop. The highest leaching of $\mathrm{NO}_{3}^{-}$was recorded at $\mathrm{N}_{130}+\mathrm{SGR}_{100}$. During wheat cropping (2012-13), the greatest amount of $\mathrm{NO}_{3}^{-}$leaching $\left(31.56 \mathrm{mg} \mathrm{L}^{-1}\right)$ was recorded with $\mathrm{N}_{130}+\mathrm{SGR}_{100}$ which did not differ significantly from $\mathrm{NO}_{3}^{-}$leaching at $\mathrm{N}_{130}+\mathrm{SGR}_{50}$, while the smallest amount of $\mathrm{NO}_{3}^{-}$leaching $\left(10.63 \mathrm{mg} \mathrm{L}^{-1}\right)$ was observed at control treatment (Figure 3). A significant decrease in $\mathrm{NO}_{3}{ }^{-}$in second leachate was observed as compared to first leachate. The minimum $\mathrm{NO}_{3}{ }^{-}$concentration was recorded at control treatment and the highest was at $\mathrm{N}_{130}+\mathrm{SGR}_{100}$. An increase in $\mathrm{NO}_{3}^{-}$contents was observed in third leachate with respect to second where the highest $\mathrm{NO}_{3}{ }^{-}$concentration (31.90 $\mathrm{mg} \mathrm{L}^{-1}$ ) was observed at $\mathrm{N}_{130}+\mathrm{SGR}_{100}$ and the lowest $\left(8.98 \mathrm{mg} \mathrm{L}^{-1}\right)$ at control treatment. Overall, the maximum $\mathrm{NO}_{3}^{-}$leaching was noted at $\mathrm{N}_{130}+\mathrm{SGR}_{100}$, while the minimum $\mathrm{N}$ leaching occurred with the control treatment during rice-wheat crop production. 


\subsection{Nitrogen uptake by rice and wheat crops}

The effect of gypsum and $\mathrm{N}$ application rates on $\mathrm{N}$ uptake by rice (paddy and straw) and wheat (grain and straw) in both years has been presented in Table 3. In both years, the highest $\mathrm{N}$ uptake was recorded at treatment $\mathrm{N}_{130}+\mathrm{SGR}_{100}$. In rice 2011, the highest nitrogen uptake recorded in paddy and straw was 19.51 and $29.15 \mathrm{~kg} \mathrm{ha}^{-1}$, respectively. While during second year, the highest $\mathrm{N}$ contents in paddy and straw were 37.24 and $49.82 \mathrm{~kg} \mathrm{ha}^{-1}$, respectively. The highest uptake in rice was observed with $\mathrm{N}_{130}+\mathrm{SGR}_{100}$ for both years and the lowest was with control treatment

Similarly, in wheat grain and straw, maximum nitrogen uptake was recorded at treatment $\mathrm{N}_{130}+$ $\mathrm{SGR}_{100}$ in both years. In wheat 2011-12, the highest $\mathrm{N}$ uptake by grain and straw was 45.92 and 65.23 $\mathrm{kg} \mathrm{ha}^{-1}$, respectively. While during second year, the highest recorded uptake of $\mathrm{N}$ was 56.02 and 65.83 $\mathrm{kg} \mathrm{ha}^{-1}$, respectively which also differed significantly from the respective control treatment.

Table 3. Effect of applied $\mathrm{N}$ rates on nitrogen uptake $\left(\mathrm{kg} \mathrm{ha}^{-1}\right)$ of wheat and rice on salt-affected soil, where (C) no fertilizer and no gypsum, $\left(\mathrm{N}_{100}+\mathrm{SGR}_{50}\right)$ recommended $\mathrm{N}+$ gypsum at $50 \% \mathrm{SGR},\left(\mathrm{N}_{130}+\mathrm{SGR}_{50}\right) 30 \%$ higher $\mathrm{N}$ than recommended $\mathrm{N}$ fertilizer + gypsum at $50 \% \mathrm{SGR}$, and $\left(\mathrm{N}_{100}+\mathrm{SGR}_{100}\right)$ recommended $\mathrm{N}+$ gypsum @ 100 $\%$ SGR, and $\left(\mathrm{N}_{130}+\mathrm{SGR}_{100}\right) 30 \%$ higher $\mathrm{N}$ than recommended $\mathrm{N}$ fertilizer + gypsum at $100 \% \mathrm{SGR}$.

\begin{tabular}{|l|l|l|l|l|l|l|l|l|}
\hline Treatment & \multicolumn{2}{|l|}{ Rice 2011 } & \multicolumn{2}{l|}{ Wheat $2011-12$} & \multicolumn{2}{l|}{ Rice 2012 } & \multicolumn{2}{l|}{ Wheat 2012-13 } \\
\hline & Paddy & Straw & Grain & Straw & Paddy & Straw & Grain & Straw \\
\hline $\mathrm{C}$ & $10.92 \mathrm{e}$ & $19.72 \mathrm{~d}$ & $20.08 \mathrm{e}$ & $35.87 \mathrm{~d}$ & $15.27 \mathrm{~d}$ & $27.04 \mathrm{~d}$ & $22.78 \mathrm{~d}$ & $32.71 \mathrm{~d}$ \\
\hline $\mathrm{N}_{100}+\mathrm{SGR}_{50}$ & $13.49 \mathrm{~d}$ & $22.77 \mathrm{c}$ & $28.46 \mathrm{~d}$ & $46.41 \mathrm{c}$ & $23.38 \mathrm{c}$ & $34.57 \mathrm{c}$ & $34.10 \mathrm{c}$ & $45.50 \mathrm{c}$ \\
\hline $\mathrm{N}_{130}+\mathrm{SGR}_{50}$ & $17.30 \mathrm{~b}$ & $26.60 \mathrm{ab}$ & $39.32 \mathrm{~b}$ & $56.02 \mathrm{~b}$ & $29.20 \mathrm{~b}$ & $40.97 \mathrm{~b}$ & $43.73 \mathrm{~b}$ & $57.94 \mathrm{~b}$ \\
\hline $\mathrm{N}_{100}+\mathrm{SGR}_{100}$ & $15.49 \mathrm{c}$ & $25.15 \mathrm{bc}$ & $35.47 \mathrm{c}$ & $48.45 \mathrm{c}$ & $29.06 \mathrm{~b}$ & $43.10 \mathrm{~b}$ & $52.51 \mathrm{a}$ & $63.60 \mathrm{a}$ \\
\hline $\mathrm{N}_{130}+\mathrm{SGR}_{100}$ & $19.51 \mathrm{a}$ & $29.15 \mathrm{a}$ & $45.92 \mathrm{a}$ & $62.23 \mathrm{a}$ & $37.24 \mathrm{a}$ & $49.82 \mathrm{a}$ & $56.02 \mathrm{a}$ & $65.83 \mathrm{a}$ \\
\hline LSD & $1.36^{*}$ & $2.61^{*}$ & $2.81^{*}$ & $4.45^{*}$ & $2.87^{*}$ & $3.87^{*}$ & $3.97^{*}$ & $2.93^{*}$ \\
\hline
\end{tabular}

* Treatments differed significantly at $p \leq 0.05$.

\subsection{Pearson correlation between physicochemical properties of soil and yield parameters}

Data showed inverse relationships between EC, $\mathrm{pH}, \mathrm{SAR}$ and $\mathrm{CaCO}_{3}$ with grain and straw yield $(p$ $\leq 0.01$ ) while $\mathrm{CEC}$ and $\mathrm{OM}$ correlated positively with the yield at $5 \%$ level of significance (Table $4)$. With respect to bulk density (BD), the highest significant values of correlation coefficient (r) were observed with grain and straw yield i.e. -0.9506 and -0.9705 , respectively. The values of correlation coefficients between IR and yield were highly significant ( $p \leq 0.01$ ), and the highest values were 0.8861 and 0.8627 with grain and straw, respectively. Furthermore, there were negative correlations between NUE and soil chemical properties ( $\mathrm{EC}, \mathrm{pH}, \mathrm{SAR}$ and $\mathrm{CaCO}_{3}$ ), and values of correlation coefficient for NUE were significantly higher than infiltration rate (IR). However, the highest $\mathrm{r}$ values of NUE with OM, grain, and CEC were $0.9695,0.8962$, and 0.8253 , respectively. 
Table 4. Pearson correlation coefficients (r) between physicochemical properties of soil and yield parameters after 2 year of experiments

\begin{tabular}{|c|c|c|c|c|c|c|c|c|c|c|}
\hline & $\mathrm{BD}$ & CEC & $\mathrm{CaCO}_{3}$ & EC & Grain & IR & NUE & OM & $\mathrm{pH}$ & SAR \\
\hline CEC & -0.9864 & & & & & & & & & \\
\hline $\mathrm{CaCO}_{3}$ & 0.9163 & -0.9003 & & & & & & & & \\
\hline $\mathrm{EC}$ & 0.7371 & -0.7170 & 0.9458 & & & & & & & \\
\hline Grain & -0.9506 & 0.9887 & -0.8650 & -0.6827 & & & & & & \\
\hline IR & -0.9536 & 0.9300 & -0.7577 & -0.5090 & 0.8861 & & & & & \\
\hline NUE & -0.7263 & 0.8253 & -0.7249 & -0.6189 & 0.8962 & 0.5956 & & & & \\
\hline $\mathrm{OM}$ & -0.5464 & 0.6748 & -0.5391 & -0.4469 & 0.7758 & 0.4264 & 0.9695 & & & \\
\hline $\mathrm{pH}$ & 0.8209 & -0.9033 & 0.7620 & 0.6073 & -0.9568 & -0.7300 & -0.9828 & -0.9256 & & \\
\hline SAR & 0.9842 & -0.9959 & 0.9345 & 0.7765 & -0.9831 & -0.9022 & -0.8325 & -0.6765 & 0.8997 & \\
\hline Straw & -0.9705 & 0.9841 & -0.9569 & -0.8251 & 0.9733 & 0.8627 & 0.8454 & 0.6897 & -0.8990 & -0.9960 \\
\hline
\end{tabular}

BD: bulk density, $\mathrm{CEC}$ : cation exchange capacity, $\mathrm{CaCO}_{3}$ : calcium carbonate, EC: electrical conductivity, IR: infiltration rate, NUE: nitrogen use efficiency, OM: organic matter, SAR: sodium adsorption ratio

\subsection{Economic evaluation}

The practical economics of the experiments were calculated using the market prices of common and variable inputs while toll prices of rice and wheat (Table 5). The agriculture on degraded and poor soils is generally less attractive because of high initial cost for soil reclamation. The gross income was maximum with addition of $\mathrm{N}_{130}+\mathrm{SGR}_{100}$. The yield gap between the salt-affected and normal soil decreased from $53 \%$ to $26 \%$ at $\mathrm{N}_{130}+\mathrm{SGR}_{100}$.
While, benefit cost ratio estimation revealed that rice-wheat cropping system is profitable with treatment $\mathrm{N}_{100}+\mathrm{SGR}_{100}$ as compared to other treatments (Table 5) However, investment is profitable in rice-wheat production at $\mathrm{N}_{100}+\mathrm{SGR}_{100}$ since an investment of $1 \mathrm{PKR}$, it gains $2.15 \mathrm{PKR}$ with net return of $1.15 \mathrm{PKR}$. It is encouraging to note that the cost of treatments has been recovered from the first crop, while in subsequent year; treatment $\mathrm{N}_{100}$ $+\mathrm{SGR}_{100}$ became more profitable. 
Table 5. Economics of applied treatments for rice and wheat (two each) crops from salt-affected soils, where (C) no fertilizer and no gypsum, $\left(\mathrm{N}_{100}+\mathrm{SGR}_{50}\right)$ recommended $\mathrm{N}+$ gypsum at $50 \% \mathrm{SGR},\left(\mathrm{N}_{130}+\mathrm{SGR}_{50}\right) 30 \%$ higher $\mathrm{N}$ than recommended $\mathrm{N}$ fertilizer + gypsum at $50 \% \mathrm{SGR}$, and $\left(\mathrm{N}_{100}+\mathrm{SGR}_{100}\right)$ recommended $\mathrm{N}+$ gypsum @ 100 $\%$ SGR, and $\left(\mathrm{N}_{130}+\mathrm{SGR}_{100}\right) 30 \%$ higher $\mathrm{N}$ than recommended $\mathrm{N}$ fertilizer + gypsum at $100 \% \mathrm{SGR}$.

\begin{tabular}{|l|c|c|c|c|}
\hline Treatment & $\begin{array}{l}\text { Total Cost } \\
\left(\text { Pak Rs.ha }^{-1}\right)\end{array}$ & $\begin{array}{l}\text { Total Revenue } \\
\left(\text { Pak Rs ha }^{-1}\right)\end{array}$ & $\begin{array}{l}\text { Net benefit } \\
\left(\text { Pak Rs. ha }^{-1}\right)\end{array}$ & $\begin{array}{l}\text { Benefit Cost } \\
\text { Ratio }\end{array}$ \\
\hline $\mathrm{C}$ & 118190 & 228473 & 110283 & 1.93 \\
\hline $\mathrm{N}_{100}+\mathrm{G}_{50}$ & 149885 & 291905 & 142020 & 1.95 \\
\hline $\mathrm{N}_{130}+\mathrm{G}_{50}$ & 168973 & 342045 & 173072 & 2.02 \\
\hline $\mathrm{N}_{100}+\mathrm{G}_{100}$ & 160154 & 344465 & 184312 & 2.15 \\
\hline $\mathrm{N}_{130}+\mathrm{G}_{100}$ & 178830 & 375023 & 196193 & 2.10 \\
\hline
\end{tabular}

Pak Rs=Pakistani rupees

Benefit Cost Ratio $=$ TR/TC, TR mentions the total revenue, which properly analyzed as the benefit generated through rice-wheat production. TC remarked as the total cost appropriately evaluated as the total expenditures of rice-wheat cultivation.

\section{Discussion}

Nitrogen cycling in soil-plant system is very dynamic and complex due to climatic, soil, and plant factors and their interactions (Fageria and Baligar, 2005). The fraction of the applied $\mathrm{N}$ not taken up by plants is vulnerable to loses by volatilization, denitrification and leaching. The NUE can be increased by improving uptake efficiency of the $\mathrm{N}$ inputs, thereby minimizing the aforementioned losses and potentially reducing environmental risks (Ladha et al., 2016; Ortega et al. 2016). Adoption of new management strategies, such as cropping systems, affects $\mathrm{C} / \mathrm{N}$ ratio, and organic and inorganic pools of $\mathrm{N}$ in the soil. In this study, during rice growth, submerged soil having high leaching fraction (LF) promoted desalination and desodication of calcareous soils due to valence dilution, in-situ mineral weathering and root action (Jenny, 2012). The decrease in $\mathrm{pH}_{\mathrm{s}}$ at $\mathrm{N}_{100}+\mathrm{SGR}_{100}$ could be attributed to supply of $\mathrm{Ca}^{2+}$ followed by leaching of $\mathrm{Na}^{+}$salts below $30 \mathrm{~cm}$ soil layer in saline-sodic soils (Table 1). However, at $0-15 \mathrm{~cm}$ soil depth during rice crop, $\mathrm{NH}_{4}{ }^{+}$along with gypsum may decrease $\mathrm{pH}_{\mathrm{s}}$, increase leaching, permeability, macro porosity and flocculation, lower bulk density and reduce surface crusting (Rengasamy, 2010). Treatment $\mathrm{N}_{130}+\mathrm{SGR}_{100}$ and $\mathrm{N}_{100}$ $+\mathrm{SGR}_{100}$ remained better to lower the $\mathrm{EC}_{\mathrm{e}}$ because of improved IR of water (Table 1). Heavy irrigation water to rice crop increased leaching of soluble salts, lowering $\mathrm{EC}_{\mathrm{e}}$ more effectively at $0-15 \mathrm{~cm}$ soil depth compared to $\mathrm{EC}_{\mathrm{e}}$ at $15-30 \mathrm{~cm}$ soil depth. In gypsum added plots, the composition of soil solution had higher levels of $\mathrm{Ca}^{2+}$ that might have favored the sustainability in IR and HC. All the treatments significantly lowered soil SAR after rice and wheat harvest and gypsum application was highly effective in lowering soil SAR by decreasing dispersion through $\mathrm{Na}^{+}-\mathrm{Ca}^{2+}$ exchange (Qadir et al. 2014). 
The crop NUE is controlled by N uptake and assimilation. Nitrate taken up by plant roots is assimilated in the roots while its major part is transported to the shoots where it is transformed to $\mathrm{NH}_{4}^{+}$in the cytoplasm (Lam et al., 1996). Ammonium ions in the solution are generally bound to negatively charged soil surfaces and transported to surface water bodies through runoff, whereas excessive $\mathrm{NO}_{3}^{-}-\mathrm{N}$ is leached from vadose zone to the phreatic zone, thereby contaminating the water in aquifers (Howden et al., 2013). The most relevant measure of the plant physiological NUE is the change in grain/paddy yield per unit accumulation of $\mathrm{N}$ in plant biomass. The higher paddy and wheat grain yield with $\mathrm{N}$ and gypsum application is due to induced growth that encouraged plant tolerance against the predominant EC and SAR stresses. Relatively higher yield with gypsum may be owing to its favorable effects on soil physical and chemical properties (e.g. improving soil permeability, hydraulic conductivity), particularly with favorable $\mathrm{Ca}^{2+}: \mathrm{Na}^{+}$ratios in the soil solution (Murtaza et al., 2009). The broadcasting of gypsum along with $\mathrm{N}$ has a greater potential to decrease the soil salinity, resultantly, increased rooting depth and uptake rates of $\mathrm{N}$, $\mathrm{P}, \mathrm{K}, \mathrm{Ca}, \mathrm{Cu}$ and $\mathrm{Mn}$. Decline in soil alkalinity usually leads to deeper rooting, and higher water and $\mathrm{N}$ uptake by plants (Fageria and Baligar, 2005). The N dose is directly related to the rice crop yield as the $\mathrm{N}$ requirement of rice crop depends upon the targeted yield (Prasad, 2006)

During wheat cropping in 2012-13, the highest AUE with $\mathrm{N}_{100}+\mathrm{SGR}_{100}$ on saline-sodic soil could have been due to improved soil properties i.e. $\mathrm{EC}_{\mathrm{e}}$ decreased from 10.53 to $7.27 \mathrm{dS} \mathrm{m}^{-1}$ and SAR from 41.33 to $26.48\left(\mathrm{mmol} \mathrm{L}^{-1}\right)^{1 / 2}$ (Table 1$)$. The relationship between $\mathrm{N}$ dose and paddy yield was significant (Figure 1) and showed that yield increased with increasing $\mathrm{N}$ dose up to a certain level and thereafter, at constant rate with subsequent dose of N (Singh et al., 2010). The NUE decreased with increasing $\mathrm{N}$ dose which is consistent with the diminishing law of return. Excessive application of $\mathrm{N}$ in rice increased leaching losses due to heavy irrigation requirements of rice which has detrimental impacts on the diversity and functioning of non-agricultural bacterial and plant ecosystems (Galloway et al., 2013). The Ca ions decrease the soil $\mathrm{pH}$ by precipitating carbonates and by forming a complex Ca-soil replacing $\mathrm{Na}^{+}$and ultimately leaching the $\mathrm{Na}^{+}$from root zone. Calcium also improves the $\mathrm{N}$ uptake by plant roots especially when the plants are young, and preserves the structural and functional integrity of plant membranes, stabilizes cell wall structures, regulates ion transport and controls ion exchange behavior as well as cell enzyme activity (Läuchli and Grattan, 2007).

Primary sources of inorganic $\mathrm{N}$ taken up by the plant roots are $\mathrm{NH}_{4}^{+}-\mathrm{N}$ and $\mathrm{NO}_{3}^{-}-\mathrm{N}$. During rice production in 2011, there was a gradual increase in $\mathrm{NO}_{3}{ }^{-}$concentration in the third, fourth and fifth leachates (Figure $3)$. As observed above, the higher $\mathrm{NO}_{3}^{-}$content in fifth leachate seemed due to the third $\mathrm{N}$ application coupled with a decrease in $\mathrm{N}$ absorption just before crop maturity. Higher than permissible $\mathrm{NO}_{3}^{-}$especially in the first leachates was recorded at $\mathrm{N}_{130}+\mathrm{SGR}_{100}$ which not only decreases fertilizer use efficiency but also contaminates groundwater reservoir (Boufekane and Saighi, 2015). During rice crop of 2012, an increase in leached $\mathrm{NO}_{3}{ }^{-}$contents observed during third and fourth leaching seems due to the improvements in IR and $\mathrm{HC}$ with the use of gypsum (Gharaibeh et $a l ., 2009)$ by aggregating soil particles. Increased aggregate stability in gypsum amended soils suggests formation of strong bonding involving $\mathrm{Ca}^{2+}$ bridges (Bronick and Lal, 2005).

During wheat 2011-12, the maximum $\mathrm{NO}_{3}^{-}$concentration observed in the first leachate was at treatment $\mathrm{N}_{130}+\mathrm{SGR}_{100}$ which did not differ significantly from $\mathrm{N}_{130}+\mathrm{SGR}_{50}$. A significant decrease in $\mathrm{NO}_{3}^{-}$ 
leaching in the second leachate was attributed to increased uptake of $\mathrm{NO}_{3}^{-}$by plants during the vegetative growth period. The observed increase in $\mathrm{NO}_{3}^{-}$contents in third leachate could be due to the ameliorative role of gypsum which enhanced soil flocculation, and increased IR and HC of soil. Yazdanpanah (2013) reported that during reclamation process of saline-sodic soils in consequence of leaching, $\mathrm{N}$ tends to be removed out of soil profile. Several studies documented adverse effects of high $\mathrm{NO}_{3}^{-}$levels, most notably methemoglobinemia, stomach cancer and non-Hodgkin's Lymphoma (Ward et al., 1994).

Although the highest yield was obtained when 30\% extra $\mathrm{N}$ was applied with $100 \%$ gypsum addition and the benefit cost ratio was also better, nevertheless considering highest $\mathrm{NO}_{3}$ leaching it cannot be recommended. The treatments $\mathrm{N}_{100}+\mathrm{SGR}_{50}$ and $\mathrm{N}_{100}$ $+\mathrm{SGR}_{100}$ produced promisingly higher yield with low $\mathrm{NO}_{3}$ leaching which seems better option for sustainable crop production (Figure 3).

\section{Conclusions}

The results of this study showed that the highest $\mathrm{NO}_{3}^{-}$leaching for rice and wheat was observed with $\mathrm{N}_{130}+\mathrm{SGR}_{100}$ but remained higher for wheat than for rice during reclamation of saline-sodic soil. In this treatment, crop yield and AUE were also the highest as compared to the other combinations. Recommended and higher levels of $\mathrm{N}$ fertilizer increased the growth and yield of rice and wheat when applied along with gypsum. Application of higher $\mathrm{N}$ fertilizer $\left(\mathrm{N}_{130}\right)$ had maximum yield for rice and wheat, nevertheless the net returns were not economical for the latter case. Economic returns of wheat were observed at recommended dose of $\mathrm{N}$ along with gypsum as per reclamation requirements. All these observations led us to conclude that the treatment $\mathrm{N}_{100}+\mathrm{SGR}_{100}$ would be environmental friendly and economically viable option for rice-wheat cropping system in salinesodic soils.

\section{Acknowledgements}

The authors gratefully acknowledge Higher Education Commission (HEC) of Pakistan for financial assistance to carry out this research work. Special thanks are due to Prof. Dr. Abdul Ghafoor and Prof. Dr. Rien Van Genuchten for their valuable feedback on the manuscript.

\section{References}

Abdelgadir, E., Fadul, E., Fageer, E., Ali, E. 2010. Response of wheat to nitrogen fertilizer at reclaimed high terrace salt-affected soils in Sudan. Journal of Agriculture and Social Sciences. 6, 43-47.

Arshad, M., 1999. Nitrogen nutrition management and fertilizer use efficiency in wheat undeu different soil conditions. Ph.D. Thesis Dep. Biol. Sci., Quaid-i-Azam University, Islamabad, Pakistan.

Boufekane, A., Saighi, O. 2015. Effect of recharge, irrigation and soil nature on the variation of nitrate in the groundwater of Wadi Nil (Jijel NorthEast Algeria). African Journal of Agricultural Research. 10, 720-726.

Bronick, C.J., Lal, R. 2005. Soil structure and management: a review. Geoderma. 124, 3-22.

Estefan, G., Sommer, R., Ryan, J. 2013. Methods of soil, plant, and water analysis: A manual for the west, Asia and North Africa region. ICARDA, Beirut, Lebanon.

Fageria, N., Baligar, V. 2005. Enhancing nitrogen use efficiency in crop plants. Advances in Agronomy. 88, 97-185. 
Feizi, M., Hajabbasi, M.A., Mostafazadeh-Fard, B. 2010. Saline irrigation water management strategies for better yield of safflower (Carthamus tinctorius L.) in an arid region. Australian Journal of Crop Science. 4, 408-414.

Galloway, J.N., Leach, A.M., Bleeker, A., Erisman, J.W. 2013. A chronology of human understanding of the nitrogen cycle. Philosophical Transactions of the Royal Society B: Biological Sciences. 368, 20130120.

Ghafoor, A., Qadir, M., Murtaza, G. 2004. Salt-affected soils: principles of management. Allied Book Centre, Lahore, Pakistan.

Gharaibeh, M.A., Eltaif, N.I., Shunnar, O.F. 2009. Leaching and reclamation of calcareous salinesodic soil by moderately saline and moderate SAR water using gypsum and calcium chloride. Journal of Plant Nutrition and Soil Science. 172, 713-719.

Ghassemi, F., Jakeman, A.J., Nix, H.A., 1995. Salinisation of land and water resources: human causes, extent, management and case studies. CAB international, Australia.

Grattan, S., Grieve, C. 1999. Mineral nutrient acquisition and response by plants grown in saline environments. Handbook of Plant and Crop Stress. 2, 203-229.

Havlin, J., Beaton, J.D., Tisdale, S.L., Nelson, W.L., 2005. Soil fertility and fertilizers: An introduction to nutrient management. Pearson Prentice Hall Upper Saddle River, NJ. USA.

Howden, N.J., Burt, T.P., Worrall, F., Mathias, S.A., Whelan, M.J. 2013. Farming for water quality: Balancing food security and nitrate pollution in UK river basins. Annals of the Association of American Geographers. 103, 397-407.

Jenny, H., 2012. The soil resource: origin and behavior. Springer Science \& Business Media. NY, USA.
Khan, G. 1998. Soil salinity/sodicity status in Pakistan. Soil Survey of Pakistan, Lahore. 59.

Ladha, J., Tirol-Padre, A., Reddy, C., Cassman, K., Verma, S., Powlson, D., van Kessel, C., Richter, D.d.B., Chakraborty, D., Pathak, H. 2016. Global nitrogen budgets in cereals: A 50-year assessment for maize, rice, and wheat production systems. Scientific reports. 6 .

Lam, H.-M., Coschigano, K., Oliveira, I., MeloOliveira, R., Coruzzi, G. 1996. The moleculargenetics of nitrogen assimilation into amino acids in higher plants. Annual Review of Plant Biology. 47, 569-593.

Läuchli, A., Grattan, S., 2007. Plant growth and development under salinity stress, Advances in molecular breeding toward drought and salt tolerant crops. Springer, pp. 1-32.

Makoi, J.H., Verplancke, H. 2010. Effect of gypsum placement on the physical chemical properties of a saline sandy loam soil. Australian Journal of Crop Science. 4, 556-563.

Marschner, H., 2011. Marschner's mineral nutrition of higher plants. Academic press.

Munns, R., James, R.A., Läuchli, A. 2006. Approaches to increasing the salt tolerance of wheat and other cereals. Journal of Experimental Botany. 57, 1025-1043.

Murtaza, G., Ghafoor, A., Kahlon, U.Z., Bhatti, A.S., Sabir, M. 2009. Evaluation of rice and wheat cultivars for tolerance to salinity and sodicity in soil. Communications in Soil Science and Plant Analysis. $40,1268-1281$.

Murtaza, B., Murtaza, G., Sabir, M., Owens, G., Abbas G., Imran, M., Shah, G.M. 2017. Amelioration of saline-sodic soil with gypsum can increase yield and nitrogen use efficiency in rice-wheat cropping system. Archives of Agronomy and Soil Science. 63, 1267-1280. 
Ortega, I.L. Alfaro, M., Martinez-Lagos, J. 2016. Soil nitrogen contribution to grasslands yield in southern Chile its implications for nitrogen use efficiency nitrogen use efficiency. Journal of Soil Science and Plant Nutrition. 16, 310-322.

Prasad, R. 2006. Nitrogen uptake pattern as a guide for nitrogen application practices in rice. Indian Journal of Fertilisers. 2, 39-41.

Qadir, M., Quillérou, E., Nangia, V., Murtaza, G., Singh, M., Thomas, R.J., Drechsel, P., Noble, A.D., 2014. Economics of salt-induced land degradation and restoration, Natural Resources Forum. Wiley Online Library, pp. 282-295.

Rengasamy, P. 2010. Soil processes affecting crop production in salt-affected soils. Functional Plant Biology. 37, 613-620.

Rowell, D.L., 2014. Soil science: Methods \& applications. Routledge. New York, USA.

Rozema, J., Flowers, T. 2008. Crops for a salinized world. Science. 322, 1478-1480.

Shrivastava, P., Kumar, R. 2015. Soil salinity: A serious environmental issue and plant growth promoting bacteria as one of the tools for its alleviation. Saudi Journal of Biological Sciences. 22, 123-131.
Singh, S., Malik, R., Dhankar, J., Yadav, A., Garg, R., Kamboj, B., Sheoran, P., Lathwal, O. 2010. Nutrient use pattern in the irrigated rice-wheat cropping system in the Indo-Gangetic plains of Haryana, India. Experimental Agriculture. 46, 191-209.

Steel, R.G.D., Torrie, J.H., Dickey, D.A. 1997. Principles and Procedures of Statistics. McGraw Hill Co. Inc., New York, USA.

Walia, M.K., Dick, W.A. 2016. Soil chemistry and nutrient concentrations in perennial ryegrass as influenced by gypsum and carbon amendments. Journal of Soil Science and Plant Nutrition. $16,832-847$.

Ward, M.H., Zahm, S.H., Weisenburger, M.D.D., Gridley, M.G., Cantor, K.P., Saal Yazdanpanah, N., Pazira, E., Neshat, A., Mahmoodabadi, M., Sinobas, L.R. 2013. Reclamation of calcareous saline sodic soil with different amendments (II): Impact on nitrogen, phosphorous and potassium redistribution and on microbial respiration. Agricultural Water Management. 120, 39-45. 